\title{
OS USOS AMBÍGUOS DO ARGUMENTO DO CONFLITO EM MAQUIAVEL E ARISTÓTELES ${ }^{1}$
}

\author{
Raul Francisco Magalhães
}

\begin{abstract}
RESUMO
O artigo apresenta uma reflexão sobre a necessidade do uso de uma argumentação ambígua para tratar o tema do conflito em dois autores clássicos: Maquiavel e Aristóteles. A idéia é que ambos os autores foram forçados a discutir o tema do conflito social de maneira ambivalente, em um momento segundo uma diretriz comum e criticando o conflito como a perdição da ordem e, em outro, vendo o conflito como uma força capaz de levar a uma forma superior de ordem política. De fato, em Aristóteles, o conflito pode tanto ser causa geradora de estabilidade de classes e de constituição para a forma virtuosa da democracia (a politéia) quanto da instalação da decadência na ordem constitucional. Em Maquiavel, o conflito é causa da liberdade que sustenta a república, tendo Roma como modelo, e também da infindável desagregação da república, tendo Florença como modelo. A sugestão para o debate é que essa ambigüidade, no caso, é radicada na necessidade de compatibilizar uma característica metafisica do quadro analítico desses autores, ou seja, o tempo circular da história, contraposto aos requerimentos analíticos empíricos que deveriam ser explicados pelas teorias do autor grego e do italiano. A comparação entre Maquiavel e Aristóteles baseia-se no fato de ambos terem, a despeito das enormes diferenças entre suas obras, enfrentado um tema comum, ou seja a noção de circularidade da história como um problema para resolver leituras mais realistas sobre o conflito de classes.
\end{abstract}

PALAVRAS-CHAVE: Maquiavel; Aristóteles; argumentação; conflito.

\section{INTRODUÇÃO}

Considerar questões de retórica na análise de textos clássicos de teoria política certamente não é uma metodologia heterodoxa. Ao contrário, desde os anos 1980 e 1990, sobretudo pela linhagem dos trabalhos derivados de Quentin Skinner, passamos a perceber os autores como agentes premidos por circunstâncias históricas e analíticas que os levaram, freqüentemente, a aparentes (às vezes reais) contradições argumentativas. Os autores aqui escolhidos são também personagens de um tempo no qual a retórica, como disciplina, era central na forma de organizar e apresentar idéias: sociedades como a polis ateniense e a república florentina. No caso presente, pretendemos discutir os usos do argumento do conflito social em Aristóteles e Maquiavel, mostrando em ambos a

1 Este texto foi elaborado para o VII Encontro da Associação Brasileira de Ciência Política (ABCP), retomando outro originalmente publicado em Magalhães (1998). Os argumentos ali contidos foram retrabalhados, ampliados e suprimidos em função analise retórica que não estava contemplada no texto. ambigüidade desse tópico. De fato, em Aristóteles, o conflito pode tanto ser causa de estabilidade de classes e de constituição para a forma virtuosa da democracia (a politeia) quanto da instalação da decadência na ordem constitucional. Em Maquiavel o conflito é causa da liberdade que sustenta a república, tendo Roma como o modelo, e também é causa da infindável desagregação da república, tendo Florença como modelo. A sugestão para o debate é de que essa ambigüidade, no caso, é radicada na necessidade de compatibilizar uma característica metafísica ${ }^{2}$ do quadro analítico, ou seja, a idéia de tempo circular da história, contraposto aos requerimentos analíticos empíricos que deveriam ser explicados pelas teorias do grego e do italiano. Em suma, o conflito faz girar a roda das constituições históricas para o lado da seqüencia lógica das formas de governo e, por isso, pode alcançar pontos de equilíbrio constitucionais, compatíveis com a estabilidade, cuja ima-

2 Por "metafísica" entendemos o conjunto de idéias são tratadas como requisitos a priori para a compreensão de um conceito ou fenômeno. 
gem metafísica é a imobilidade do tempo. "Outro" conflito faz girar essa "roda" em uma seqüência empírica incompatível com a circularidade, levando a constituições instáveis na história. Surge aí o espaço para a análise do protagonismo dos atores coletivos ou personagens individuais conquistadoras.

Faz parte da boa lógica, e dos usos retóricos dela, que afirmações contraditórias não sejam compatíveis com a verdade de suas conclusões, o que significa que a contradição é o indicador por excelência do erro de raciocínio. Paradoxalmente, a renovada escola de estudos da retórica e da argumentação no século XX (PERELMAN \& OLBRECHTS-TYTECA, 1996; TOULMIN, 1997; MEYER, 1998; MAGALHAES, 2000), somada aos estudos críticos sobre os procedimentos da ciência, estabeleceram a incapacidade dos sistemas teóricos resolverem todas as suas questões com base em suas premissas internas, o que os força normalmente a contrabandear argumentos exógenos para resolver certos casos limite. Além disso, mostraram também como os mesmos sistemas teóricos podem cair em circularidades infinitas, em tautologias, se insistimos em permanecer exclusivamente nos marcos de suas premis$\mathrm{sas}^{3}$. Grandes autores raramente intimidaram-se diante de contradições, mesmo porque a tarefa analítica deve impor suas necessidades e, no caso de Aristóteles e Maquiavel, estamos diante de pensadores premidos por mudanças brutais da realidade histórica ao redor, o império macedônio e a crise das repúblicas italianas no Renascimento ${ }^{4}$.

3 Essa discussão é tributária de Kurt Gödel, que formulou a idéia de que nenhum sistema de axiomas pode ser suficiente para provar o conjunto de conseqüências que deles pode ser extraída, o que leva à necessidade, para certos casos, de "contaminar" os sistemas de argumentação, mesmo matemáticos, com proposições exógenas. Ver Nagel e Newman (2003).

4 Os gregos nunca tiveram uma experiência de império interna à Grécia antes da ocupação macedônia. Os impérios conhecidos eram os dos sempre derrotados persas. Felipe da Macedônia e seu filho Alexandre são o fim da polis grega, na medida em que a integraram a um tipo novo de império, e Aristóteles é testemunha ocular desse fato. Depois da experiência macedônica, a cidade-estado grega não impediu a dominação romana e sucumbiu à experiência de um novo império, que sepultou definitivamente sua autonomia. Toda a experiência de autonomia da polis, responsável por nossa primeira tradição da teoria política, chocou-se contra um fato novo. Aristóteles escreve, com as
Também estamos diante de dois autores cientes da importância da retórica no quadro argumentativo da análise política. Para lembrar uma das "fichas" de Wittgenstein, eles não queriam evitar a contradição, apenas tinham de lidar com ela ${ }^{5}$.

$\mathrm{Na}$ exposição seguinte não há qualquer pretensão de erudição no trato dos autores, nem a divulgação secundária de algum dado novo de pesquisa que por ventura tenha sido publicado pelos historiadores e eruditos em pesquisas recentes. O que se pretende é discutir como o argumento relativo à positividade ou negatividade do conflito social harmoniza-se e choca-se com premissas dos sistemas teóricos gerais dos autores, e como isso leva-os a carregar sua análise do conflito de uma natureza dual, ou, mais cruamente, ambígua, para resolver suas perspectivas analíti-

tintas da tradição, que louvava a autonomia da polis, observando um tempo novo, que era a imposição do império. Da mesma forma, as cidades-repúblicas italianas, do século XIV em diante, viveram cheias de autonomia, desafiando o Sacro Império e o papado, até que os estados nacionais unificados, sobretudo a França e a Espanha, mostraram-se capazes de esmagar a Itália, exatamente porque não existia ali um estado italiano como um fato geopolítico. Havia um agregado de cidades defendidas por mercenários. Maquiavel viveu a tensão entre ser secretário de uma cidade-república e ter a consciência de que essa forma não poderia unificar a Itália, por tal tarefa requerer um exército regular e centralizado sob comando de um príncipe, tarefa prática impossível para uma república. Quanto à tarefa teórica, seria muito difícil para a tradição do humanismo cívico das cidades italianas fundamentar o direito de mando de um príncipe, uma vez que, para essa tradição, só a república é virtuosa e o principado era um passo para a tirania. Maquiavel teve de subverter essas idéias para defender o principado como uma saída para a Itália.

5 O aforismo de Wittgenstein é: “688. Gostaria de perguntar, não 'que temos de fazer para evitar uma contradição?' mas 'que devemos fazer se chegarmos a uma contradição?" (WITTGENSTEIN, 1989, p. 151). A idéia é que tanto Maquiavel quanto Aristóteles vão lidar com fortes contradições inevitáveis ao seu tempo. Maquiavel, formado na escola republicana do humanismo cívico, pediu um príncipe para unificar a Itália. Para a tradição republicana, o principado (governo de um) era facilmente identificado com a tirania. Nos Discorsi, Maquiavel fala da necessidade de um único homem refundar a república (por definição uma obra coletiva), ou seja, Maquiavel cria um oximoro, uma contradição retórica. Já Aristóteles sabia que o demos estava incorporado de fato à polis e era uma fonte de conflito com os aristocratas. Então, a melhor constituição, aquela que supera os conflitos, deveria ter como base social os agentes do conflito. Esse argumento será desenvolvido no texto. 
cas. Assim, um ponto de partida é a metafísica que ordena a noção de história em ambos e, depois, a análise textual da dualidade/ambigüidade em Maquiavel e Aristóteles e, novamente, Maquiavel.

\section{AS METAFÍSICAS DO TEMPO COMO PRE- MISSAS}

Quando alguém começa a estudar os primeiros elementos do que se chama "cultura clássica", e sua posterior reedição na Renascença, é sempre apresentado a uma idéia singular: aqueles gregos e romanos, e também seus admiradores renascentistas, concebiam o tempo como um $\mathrm{ci}$ clo no qual os eventos floresciam, decaiam e tornavam a surgir. Essa idéia é acompanhada logicamente por uma comparação com nossa concepção contemporânea de um tempo que não se repete, esvai-se. Um tempo linear que, por outras razões, estava presente na Idade Média, pois os homens partiam de um estágio inicial decaído, seguindo uma marcha rumo a Deus. Então, o tópico do tempo, que terá reflexo inevitável nas teorias da história, (a manifestação social do tempo), fala de ciclos na Antigüidade, de escatologia com o cristianismo, o retorno aos ciclos na Renascença e o reestabelecimento do progresso contínuo com a modernidade. Nossa "hipótese", bem mais modesta em termos de uma filosofia da história das formas de governo, é que podemos pensar Aristóteles e Maquiavel como personagens que entendem um sentido do tempo histórico e têm de compatibilizá-lo com dois tópicos opostos, ou seja, uma teoria da história, plena de sentido, e uma leitura empírica da história política, crítica e desencantada.

Vamos discutir apenas as tensões entre certas exigências analíticas da noção de tempo cíclico, válidas para a descrição da natureza, e outras exigências próprias da análise empírica das formas históricas de governo, fruto do conflito e dos interesses dos homens ${ }^{6}$. As articulações entre um problema geral, como a concepção de tempo, e questões específicas, relativas à mudança das for-

\footnotetext{
6 Bignotto, que analisa o entendimento sobre o tempo na Renascença italiana e procura precisar uma distinção operacional dos conceitos de tempo e história, diz: "O tempo é tanto um problema metafísico e cosmológico quanto antropológico, e pode ser pesquisado independentemente da forma como os homens vivem em comum. Já a história diz respeito necessariamente à vida em sociedade e guarda traços indissolúveis com a política" (BIGNOTTO, 1994, p. 179)
}

mas de governo, não são explícitas em Maquiavel, que era pouco afeito a sistemas filosóficos, e também não foi detalhadamente pensada por Aristóteles, ainda que este, como se deseja argumentar, se não equacionou o problema, pelo menos não deixou de observá-lo. Nos dois autores, o princípio do ciclo é quebrado ou "entortado", em um sentido argumentativo, a fim de contemplar um saber efetivo sobre o mundo da ordem humana. Outro argumento, essencial neste texto, consiste em sugerir que a solução teórica maquiaveliana para os conflitos, que leva à mudança histórica das formas de governo, é uma solução que tem semelhanças inesperadas com a filosofia política aristotélica, ou seja, tanto em um como no outro o conflito foi tratado como uma polissemia de sentidos antagônicos, dependendo da forma como se estrutura na cidade ou na republica.

\section{A CRONOSOFIA E AS FORMAS DO CON- FLITO}

Para as relações entre a circularidade do tempo que preside a história e o conflito social, vamos mobilizar o conceito de cronosofia, formulado por Pomian (1993), que consiste em trabalhar, para fins analíticos, a coexistência simultânea, histórica, empírica e discursiva de três concepções de tempo: o linear, o circular e o estacionário ${ }^{7}$. Como observa Pomian, encontra-se na Idade

7 A proposição de Pomian é que uma cronosofia toma as três formas de entendimento do tempo como interdependentes, ou seja, a circularidade para ser pensada depende do desenvolvimento da idéia de linearidade e também de tempo estacionário. O tempo estacionário é próprio das utopias e crenças milenaristas (passado, presente e futuro são idênticos); nele não há direção a seguir. O tempo linear é um tempo de diferenças em que cada estágio diferencia-se do anterior. O tempo circular possui uma direção ascendente ou descendente, conforme o ponto tomado do ciclo (POMIAN, 1993, p. 105-106). Nenhuma dessas idéias pode ser divorciada das demais para que cada uma dessas perspectivas faça individualmente sentido. A cronometria e a cronologia tornam mais clara essa ligação ao traduzir o tempo em sinais. O tempo da cronometria é necessariamente cíclico e refere-se aos instrumentos de indicação da passagem do tempo tais como calendários e relógios. Esse tempo é essencial à vida cotidiana e ao mundo das atividades práticas. Já o tempo da cronologia é necessariamente linear, ocupando-se das datações e crônicas que diferenciam um passado de um presente. A cronosofia, ou as "cronosofias", como Pomian faz questão de enfatizar, são discursos do saber sobre o tempo. Como são discursos, elas não têm unidade e são disputas sobre o sentido que se empresta ao mundo histórico, como a evolução con- 
Média, que normalmente é tida como um período de linearização escatológica, um tempo profano totalmente cíclico, seguindo os padrões pré-cristãos. A cronosofia cristã tratava a linearidade como um atributo exclusivo da história sagrada rumo ao Deus uno, já a própria Igreja e Deus eram regidos pelo tempo estacionário, ao passo que a multiplicidade dos estados, na mesma época, estava presa aos ciclos de tempo, reproduzindo teorias que foram estabelecidas pelo saber político da Antigüidade, notadamente Aristóteles e Políbio. Etse é o ponto que pretendemos detectar em Maquiavel e Aristóteles: como ambos vão lidar com metafísicas de tempo histórico, e como suas soluções são semelhantes, em um aspecto importante, para a solução do tópico das causas que fazem as constituições históricas moverem-se e ruírem, ou, por algum tempo, estacionarem em benefício da sociedade.

Uma peculiaridade do tempo cíclico, tal qual percebido na renascença, não obstante implicar a idéia de retorno à Antigüidade e de renovação frente ao estágio "bárbaro" anterior, era sua ambivalência marcante no entendimento das relações entre o presente e o passado que a história deveria repetir. Os renascentistas não acreditavam em um tempo que "girava sobre si mesmo", mas estavam conscientes de suas diferenças com o passado. $\mathrm{O}$ cristianismo e as destruições dos séculos anteriores, bem como a inexistência de algo que pudesse rivalizar em glória com o Império Romano sublinhavam a distância e a diferença entre os dois tempos. Conforme Skinner, foi precisamente a inoperância administrativa do chamado Sacro Império, autoproclamado continuador do Império Romano, que levou as cidades italianas a buscarem respaldo jurídico para a autonomia que já exerciam de fato, desde meados do século XII

tínua rumo à transcendência ou a decadência em relação a um passado próspero e feliz. A chave da idéia de cronosofia é a possibilidade de coexistência de discursos distintos sobre o tempo como condição de sua interpretação. É importante ressaltar que as alterações das concepções de tempo ligam-se diretamente ao conteúdo do saber produzido naquele mesmo tempo. Como observa Pomian (idem), as idéias de tempo relativas ao mundo político não eram, pelo menos de maneira imediata, atingidas pelo desenvolvimento da ciência. Ao contrário, sua linearidade ou circularidade são funções das relações entre saber e poder. A linearização é um ideal de um saber cumulativo. Caso o saber seja concebido como perene, a cronosofia expressará o imobilismo ou a eternidade no ciclo.
(SKINNER, 1996, p. 25-45). O caráter cíclico do tempo renascentista manifesta-se principalmente na reverência às produções artísticas e literárias, que atingiram seu nível máximo no mundo clássico e ressurgiram para um novo esplendor. Uma arte e um pensamento pagãos emergindo da espessa cobertura cristã derramada sobre elas que, contudo, não impediu sua duração e retorno. A propriedade que salvou essas obras liga-se à sua natureza, ao seu caráter de insuperabilidade estética, que se em verdade não pode ser ultrapassado, certamente pode ser igualado pela imitação. $\mathrm{O}$ limite estético é o parâmetro da circularidade 8 .

É relativamente fácil traduzir Maquiavel nesses termos. A glória de Roma deveu-se a um conjunto de grandes ações que compreendem um saber sobre a política; imitá-las significa atualizálas. O problema é que os desafios da vita activa levaram o florentino a dotar seu agente imitador da história de flexibilidade no trato teórico e prático das ações do passado como guias para o momento presente. Dois trechos de Maquiavel, um dos Discorsi e outro das Histórias florentinas, não deixam dúvidas sobre um entendimento circular do tempo como estruturador da história: "O resultado é que os que se dedicam a ler a história ficam limitados à satisfação de ver desfilar os acon-

8 A discussão sobre um tempo cronológico remete sem dúvida ao surgimento, na Renascença, dos antiquários, cujo trabalho de pesquisa dos testemunhos do passado provocaram, conforme Arnaldo Momigliano (1983), uma revolução nos métodos da historiografia, com a introdução da distinção entre fontes diretas e indiretas. Eles foram agentes cruciais na criação de um saber que incidiu na linearização do tempo, nos termos tratados aqui. Infelizmente, não é possível investigar, neste trabalho, as ligações dos antiquários com as cronosofias do Renascimento. Se a história dos pensadores políticos tomava o passado como um catálogo de exemplos atualizáveis pelas necessidades do presente, os antiquários vão encerrar o passado em outro tempo. Ele torna-se algo que aconteceu gloriosamente na era pré-cristã, o que pode ser comprovado pela excelência de suas artes e ruínas. Essas idéias conviviam lado a lado e suas contradições eram resolvidas pela crença na capacidade humana de imitar as virtudes e formas do passado. Uma referência de Maquiavel ao trabalho dos antiquários e à imitação aparece na introdução dos Discorsi: "Não posso deixar de me espantar-e de queixar-me - quando considero, de um lado, a veneração que inspira as coisas antigas (bastaria lembrar como se compra, a peso de ouro, um fragmento de estátua que se deseja ter junto de si, como adorno da casa: modelo para os que se deliciam com sua arte, esforçando-se por reproduzi-la [...]" (MAQUIAVEL, 1979, p. 17). 
tecimentos sem procurar imitá-los, julgando tal imitação mais do que difícil, impossível. Como se o sol, o céu, os homens e os elementos não fossem os mesmos de outrora; como se sua ordem, seu rumo e seu poder tivessem sido alterados" (MAQUIAVEL, 1979, p. 18).

"Costumam as províncias, as mais das vezes, nas mudanças a que são submetidas, da ordem vir à desordem, e novamente, depois, passar da desordem à ordem: porque não estando na natureza das coisas deste mundo o deter-se, quando chegam à sua máxima perfeição, não mais podendo-se elevar, convém que precipitem; e de igual maneira, uma vez caídas pelas desordens chegadas à máxima baixeza, necessariamente não podendo mais cair convém que se elevem: assim, sempre do bem se cai no mal e do mal eleva-se ao bem, porque a virtude gera tranqüilidade, a tranqüilidade o ócio, o ócio, desordem, ruína; e igualmente, da ruína nasce a ordem, da ordem a virtude, e desta, a glória e a prosperidade" (MAQUIAVEL, 1994, p. 223).

Creio ser importante sublinhar que ambas as passagens compõem introduções de capítulos, ou seja, traduzem formas da retórica e do saber próprios do seu tempo. Afirmar coisas indisputáveis, coincidentes com um sentido comum emprestado a uma noção é o primeiro passo para persuadir o auditório, avançando com idéias nem sempre tão consensuais. Algumas dessas idéias estão na base de uma fuga do próprio tempo encerrado nas passagens acima. Para estabelecer a convivência desse caráter da história, preso aos limites metafísicos da noção renascentista de tempo circular e o tema do conflito, tido como seu motor, vamos assumir as idéias de um texto que opera precisamente com a visão maquiaveliana da mudança via conflito político. Trata-se do ensaio de Gisela Bock "Civil Discord in Machiavelli's Istorie Fiorentine" (BOCK, 1990), no qual são explicitados dois conteúdos conceituais distintos para a noção de conflito civil em Maquiavel, necessários ao entendimento de sua teoria sobre a conservação e a mudança dos estados.

O propósito aqui é, em primeiro lugar, perceber implicações dessa discussão para o tratamento do tempo histórico em termos de uma cronosofia "maquiaveliana" e, portanto, de um tempo retoricamente ambivalente nesse autor. Em segundo lugar, deseja-se discutir a formulação que Gisela Bock encontra em Maquiavel sobre a dife- rença dos sentidos da discórdia para as ordens sociais em termos de sua similaridade a uma perspectiva, que podemos remontar até Aristóteles, pelo menos em termos do mesmo problema argumentativo: como dar mais de um sentido ao ciclo de tempo, conforme a forma que se elabora a história. A ligação entre Aristóteles e Maquiavel não é óbvia e aqui, é delineada com base na isomorfia de suas soluções para condenar as formas de conflito social e paradoxalmente elogiar sua função na estabilização de certas constituições na história.

A abordagem de Gisela Bock inscreve-se na perspectiva histórica das ideas in context, tendo em Quentin Skinner talvez o seu nome mais conhecido. São leituras rigorosas dos textos de época que tomam certas condições de sua produção, relativas ao contexto político que envolvia o autor e balizava-lhe os horizontes de reflexão, seja nos constrangimentos biográficos e profissionais que marcam a escrita, o que, no caso específico de Maquiavel, costuma ser sugestivamente enfatizado: um político pertencente a uma facção derrotada tentando demonstrar a utilidade do seu saber a quem quer estivesse no poder ${ }^{9}$. O procedimento dessa vertente da historiografia das idéias é interessante, principalmente se for considerado o cuidado com que os textos originais passaram a ser tratados, aparentemente liberando-os dos séculos de leitura, nos quais as idéias primeiras foram atadas a esquemas interpretativos muito diferenciados, levando um humanista republicano a ser caricaturado como um pérfido conselheiro de tiranos.

Em seu texto a historiadora aponta, como parece ser dominante no grupo "skinneriano", para uma imagem de Maquiavel como um filósofo político consistente e possuidor de uma reflexão penetrante sobre a adequação de suas proposições teóricas aos desafios empíricos que a tarefa de historiador colocava-lhe. Isso é importante, pois o que a autora deseja é tratar de uma possível confusão que o secretário apresentaria sobre os efeitos salutares ou deletérios do conflito civil. Uma

\footnotetext{
${ }^{9}$ Skinner trabalha com a correspondência de Maquiavel, a respeito do Príncipe, sugerindo persuasivamente que o secretário escreveria sempre de olho nos favores que poderia obter. Não creio que tais considerações, que se inscrevem no dilema de se Maquiavel era maquiavélico, atrapalhem uma leitura do florentino como um teórico para além dos seus interesses pessoais (SKINNER, 1988, p. 39-44).
} 
contradição entre as famosas afirmações sobre a necessidade e a positividade do conflito, contidas nos Discorsi, que fogem à tradição, e afirmações escritas nas Histórias florentinas sobre a condenação da discórdia e a exaltação da unidade. Estas últimas completamente inseridas na tradição do pensamento político. $\mathrm{O}$ argumento da historiadora será de uma contradição apenas aparente entre um livro e outro, que pode ser eclipsada por uma leitura teórica mais adequada do pensamento de Maquiavel.

As passagens dos Discorsi postas em questão são famosas, mas sempre vale a pena relê-las: "Examinemos, porém, algumas particularidades de Roma. Os que criticam as contínuas dissensões entre os aristocratas e o povo parecem desaprovar justamente as causas que asseguraram fosse conservada a liberdade de Roma, prestando mais atenção aos gritos e rumores provocados por tais dissensões do que aos seus efeitos salutares. Não querem perceber que há em todos os governos duas fontes de oposição: os interesses do povo e da classe aristocrática. Todas as leis para proteger a liberdade nascem dessa desunião, como prova o que aconteceu em Roma, onde, durante trezentos anos e mais que transcorreram entre os Tarquínios e os Gracos, as desordens havidas produziram poucos exilados, e mais raramente ainda fizeram correr sangue" (MAQUIAVEL, 1979, p. 31-40).

“[...] Acho que é preciso tolerar as discórdias que possam surgir entre o povo e o senado considerando-as como um mal necessário para alcançar a grandeza romana. Além dos motivos já alegados, pelos quais já demonstrei que a autoridade dos tribunos era indispensável à conservação da liberdade, é fácil perceber a vantagem que trazia para as repúblicas o poder de acusar - parte das atribuições dos tribunos - como se explicará no capítulo seguinte" (ibidem).

O autor que acima reconhece a luta de classes como constitutiva do processo que permitiu Roma resolver-se internamente e partir para a expansão imperial é crítico quanto às disputas em sua própria pátria. Ao olhar para Florença, ele diz: “[...] e se jamais de república alguma tais divisões foram notáveis, as de Florença foram notabilíssimas; porque a maior parte das outras repúblicas das quais se teve alguma notícia contentou-se com uma divisão com a qual, segundo os incidentes, ora melhoraram, ora arruinaram suas cidades, mas
Florença, não contente com uma, teve muitas. Em Roma, como sabem todos, depois que os reis foram destruídos, nasceu a desunião entre os nobres e a plebe, e isso permaneceu até a sua ruína; assim foi em Atenas, assim em todas as outras repúblicas que naqueles tempos floresceram. Mas em Florença de início dividiram-se os nobres, depois os nobres e o povo e por último o povo e a plebe; e muitas vezes ocorreu que uma dessas partes, que se tornara superior, dividiu-se em duas: delas nasceram tantas mortes, tantos exílios, tantas destruições de famílias quantas jamais nasceram em alguma cidade de que se tenha memória" (MAQUIAVEL, 1994, p. 19-20) ${ }^{10}$.

De acordo com Bock, Maquiavel, expressando-se em uma fusão da filosofia política com a linguagem da tradição, pôde reconhecer primeiramente um embate estrutural, gerado pela inevitabilidade do conflito entre desiguais (povo e aristocratas), que deve ser superado institucionalmente pelas leis que garantem a liberdade, e um conflito disruptivo que acontece entre iguais: as divisões entre o povo (popolo e plebe) $\mathrm{e}$ entre as diversas facções (parte, sètte) dos endinheirados e dos grandi. Em resumo, a historiadora conclui: "Ele usou termos correntes da tradição da linguagem política florentina e os transformou em categorias e tipologias, tentando teoreticamente controlar as discórdias civis classificando-as, e, politicamente, institucionalizandoas em uma estrutura constitucional" (BOCK, 1990, p. 201).

Há, portanto, diferenças e não propriamente contradições entre o autor dos Discursos e das Histórias florentinas, conclui Gisela Bock; conclusão que não precisamos ratificar. Uma vez estabelecido esse lado da questão, o argumento que oferecemos para, de certa forma, somar e problematizar o da historiadora refere-se à exis-

10 Não é bem o caso refazer aqui a análise cirúrgica de Bock, que inclui considerações sobre a recorrência de tópicos consagrados na linguagem da época; os constrangimentos retóricos aos quais Maquiavel era levado em função da política e de seus financiadores; seus méritos como historiador na manipulação de suas fontes; um simpático reconhecimento de Rousseau como bom intérprete de Maquiavel; além de uma crítica a autores contemporâneos que leram o Maquiavel dos Discursos como um prenunciador da importância dos partidos políticos. O que realmente interessa é o argumento central da autora, que afirma haver dois conceitos distintos de conflito social no filósofo florentino. 
tência de uma formulação clássica da mesma idéia percebida por ela em Maquiavel, mais precisamente em Aristóteles. A elaboração de um conceito de conflito entre as classes, que cria possibilidades de ordenamento da sociedade existindo ao lado de um conflito intraclasses, que torna a ordem institucional instável, pertence a uma das melhores tradições da teoria política grega.

\section{UM DIÁLOGO COM ARISTÓTELES}

Ninguém objeta que a redescoberta dos autores gregos e romanos foi condição essencial para o desenvolvimento e renovação do pensamento na Renascença. Skinner pontua que a redescoberta do mundo clássico, feita pelos italianos, diferentemente de outros movimentos de renovação que ocorreram na Idade Média, assinalou uma "descontinuidade radical" daquela sociedade com o mundo grego e romano. Segundo Skinner, ao final do século XIV a interpretação do mundo antigo é totalmente distinta da leitura de continuidade entre o passado clássico e o presente dos humanistas. Pode-se dizer que ao homem medieval, que se sentia continuador direto de Roma, opôs-se um homem do Renascimento, que via no passado clássico um mundo autóctone ao cristianismo e cheio de princípios teóricos e estéticos capazes de promover a crítica da tradição cristã. E no correr do século seguinte foi possível um pensamento capaz de não só atribuir singularidade ao mundo pré-cristão, mas também reconhecer a aplicabilidade dos seus ensinamentos às questões dos contemporâneos de Petrarca, e depois de Maquiavel (SKINNER, 1996, p. 105-109). Pode-se dizer com segurança que a formação humanista de Maquiavel levou-o a ter contato com a teoria política grega, talvez através de traduções latinas, de comentadores da época, ou mesmo por ter aprendido de ouvido em uma pratiche ${ }^{11}$. As pratiche eram reuniões públicas de políticos e letrados humanistas. Elas foram um mecanismo de discussão da república florentina sobre os negócios públicos e tornaram-se o espaço por excelência do exercício da retórica. A avaliação interpretativa da história, ao lado da crítica e do elogio de ações passadas e do presente, era fundamental na orientação geral das idéias, que prevaleciam no confronto das posições defendidas

11 Para uma visão mais detalhada das pratiche na formação do debate político em torno de Maquiavel, ver Bignotto (1991, p. 66-74). pelos partidos. Os Discorsi certamente foram lidos nessas sessões e Maquiavel ali também aprendeu com seus interlocutores.

Como uma das intenções deste artigo é sugerir que há uma semelhança entre Aristóteles e Maquiavel no trato do tema do conflito, com ambos percebendo em dois tempos o conflito como constitutivo da ordem política estável e como causa da sua degeneração, nada melhor que trazer o próprio Aristóteles ao debate. Não há um uso direto de Aristóteles por Maquiavel, mas há, com certeza, uma gênese, em Aristóteles, dessa noção dual do conflito. Os livros da Política que apontam ao problema são o quarto, no qual a constituição mista é discutida, e o quinto ${ }^{12}$, em que são analisadas as causas e salvaguardas contra as revoluções que surgem no interior dos estados. $\mathrm{O}$ livro cinco, em especial, já foi identificado (por mais de um autor) como tendo certos ares maquiavelianos, dada a praticidade dos conselhos dados pelo filósofo para garantir a prevenção de revoltas, até mesmo em tiranias. Aristóteles, como Maquiavel, separa duas formas de conflito estabelecendo-as em debates diferentes.

Aristóteles toma a luta entre partes da sociedade como definidora de duas formas de governo: a oligarquia e a democracia ${ }^{13}$ e de dois princípios de justiça. Na oligarquia, a generalização da desigualdade, e na democracia, a generalização da igualdade. São formas instáveis, pois não garantem seus princípios de justiça, já que a base social de cada uma também é instável: os ricos com o desejo de aumentar privilégios e o povo lutando por mais garantias para influir no poder da polis. Aristóteles resolveu essa tensão básica em dois momentos: primeiro, por meio de uma solução constitucional, uma mescla de elementos oligárquicos e democráticos buscando um equilíbrio na ordem normativa: a politeia. E, em segui$\mathrm{da}$, a ordem normativa equilibrada pelos princípios opostos sustenta-se na própria estrutura de classes, com o desenvolvimento de uma classe inter-

12 As edições da Política podem variar no ordenamento dos livros que compõem o tratado, pois há, é claro, desacordo entre os especialistas; assim, o que corresponde aqui aos livros quatro e cinco citados pode, dependendo da edição, configurar os livros seis e oito.

13 A democracia, no caso de Aristóteles, é uma forma degenerada de governo constitucional e a oligarquia uma forma degenerada de aristocracia. 
mediária capaz de amortecer os pólos básicos de conflito. Em suas palavras: "Em todos os estados, por conseguinte, há que se assinalar três divisões: os muito ricos, os muito pobres e, em terceiro lugar, os que estão entre esses dois. Assim, pois, posto que se admite que o que é moderado ou intermediário é o melhor, fica evidente que uma quantidade média de fortuna é a melhor quantidade para se possuir. Porque esse grau de riqueza é o mais apto para obedecer à razão [...]" (ARISTÓTELES, 1982, p. 835).

“[...] Seguramente o ideal de um Estado é ser constituído o mais possível de pessoas iguais, e essa semelhança se encontra de maneira primordial nas classes médias; por conseguinte um estado composto pela classe média estará necessariamente melhor constituído com respeito àqueles elementos (a oligarquia e a democracia) dos quais dissemos se compõe um Estado de modo natural" (ibidem).

Maquiavel e Aristóteles encontram-se, à maneira heraclitiana, na harmonia dos contrários. No entendimento comum de que a polaridade criada pela desigualdade é também o campo no qual as disputas políticas podem ser superadas por arranjos estruturais-institucionais, a constituição equilibrada em Aristóteles e as "leis que protegem a liberdade" em Maquiavel. Certamente não é equivocado dizer que Aristóteles toma o embate entre elementos oligárquicos e democráticos como básicos para o estabelecimento do caminho do meio, assim como o filósofo florentino, que viu nessa disputa o lugar de forjarem-se as garantias da liberdade na república. Em ambos, essa teoria não é simplesmente lógica, ela parece sempre impressionada por fatos que ocorreram na história e pelas soluções surgidas para o equacionamento de conflitos reais.

Já no livro cinco, os conflitos, causas das revoluções e discórdias nas diferentes formas de governo, são caracterizados de modo muito semelhante ao espírito das Histórias florentinas. Ao tratar das causas que dão origem às mudanças constitucionais e suas respectivas salvaguardas, Aristóteles estabelece um dos campos clássicos da Ciência Política, em uma óptica que foi repetida por séculos: descrição dos problemas de cada forma constitucional e, em seguida, proposições relativas à manutenção de cada uma delas. Tomando empiricamente as formas constitucionais, o grego quebra de saída a noção de uma seqüên- cia rigorosamente presidida pelo ciclo, sublinhando que as mudanças geradas pelas facções e lutas de partido podem levar a inúmeros arranjos: democracias tornam-se oligarquias e vice-versa ou mudam apenas de grau, configurando-se como mais ou menos oligárquicas, podem tornar-se politeia, ou deixar de sê-lo" (idem, p. 855).

Então, o tempo cíclico que indica as famosas seis formas de governo, apresentadas em sucessão lógica e consagradas em Roma por Políbio, como a seqüência inevitável dos arranjos constitucionais, é subvertida, tendo em vista nada menos que a realidade indisciplinada dos fatos. O livro cinco, que analisa o conflito disruptivo (stasis), é repleto de presentes para quem deseja um Aristóteles analítico e fiel ao mundo da observação. As causas listadas para apontar a instabilidade das constituições vão ser muito semelhantes às considerações que Maquiavel fará mais tarde em seus textos. Fala-se ali de inveja, ganância, desprezo pelo povo, poder desproporcional de uma magistratura, intriga, falta de atenção às pequenas mudanças e tudo isso cotejado com fartos exemplos históricos. Ali também a visão dos conflitos nada tem de positiva; eles levam ao quadro da revolta civil e não apontam para o caminho do meio; suas origens estão nas falhas humanas, nas disputas de facções, não tendo por base uma causa ligada à natureza do corpo social. Não se trata por certo de um paralelo rigoroso entre os dois autores, mas é impossível deixar de sublinhar uma identidade em passagens como: "Os meios empregados para dar lugar a uma revolução nas constituições são umas vezes a força e outras a fraude e o engano. A força se emprega ou bem quando os líderes revolucionários exercem a coação desde o começo, ou bem mais adiante, e em verdade o modo de empregar a fraude é também duplo: algumas vezes os revolucionários, logo após terem enganado o povo totalmente, em uma primeiro momento, alteram a constituição com o seu consentimento, enquanto que logo, na última fase, passaram a deter o governo pela força, contra a vontade do povo; por exemplo, no tempo dos 'quatrocentos' ${ }^{\text {' } 14]}$ estes enganaram o povo dizendo-lhe que o rei dos persas lhes proveria dinheiro para a guerra contra os espartanos, e logo após

14 Nome da oligarquia ateniense de 411 a.C., também referida por Aristóteles na Constituição dos atenienses, cap. 24-34 (ARISTÓTELES, 2009, p. 59-75). 
dizer-lhes essa falsidade procuraram conservar para si o controle do governo, em outros casos, eles (os líderes) persuadem o povo desde o começo, continuam e o governam com o seu consentimento" (idem, p. 865).

Esse Aristóteles, tão realista quanto um sofista, deve ter sido leitura útil aos humanistas mais "desencantados", que consideravam a força e fraude, em certas circunstâncias, meios eficientes de manutenção do poder. Obviamente quanto a isso, outros autores da Antigüidade foram tão ou mais enfáticos, porém, no caso do Renascimento, Aristóteles tem um peso maior que outros tantos sábios do passado. Na análise aristotélica das oligarquias as disputas entre notáveis e a opressão da multidão são as causas principais das revoltas, e um antigo problema que tocava profundamente Maquiavel é pontuado ali: as revoluções que vêm de "fora" pelos atos imperialistas de um Estado contra o outro (idem, p. 866-867)

Não será preciso discutir as salvaguardas que Aristóteles pensa para cada uma das formas de governo, ainda que seus conselhos, que sugerem a um tirano parecer um rei virtuoso, além de sublinhar a importância para o usurpador de destruir as elites, incitar a guerra para dar ao povo um chefe e disseminar a cizânia entre os nobres, tenham valido ao grego comparações explícitas com o florentino, logo mitigadas pelos comentadores mais zelosos. Pode-se dizer, contudo, que se não houve influência direta; pelo menos o livro cinco inscreve-se no mesmo tipo de ensinamento que foi instrumentalmente reapropriado pelo pensamento político de autores como Maquiavel.

Que conseqüências esses argumentos sobre a história têm para as idéias de temporalidade desses filósofos? No que toca o tempo, o livro cinco ainda guarda surpresas, e permite recolocar o tema principal deste trabalho. Aristóteles não segue a cronosofia cíclica de modo radical, porque esta não the permite explicar todos os câmbios imprevistos que podem resultar das revoltas, gerando empiricamente seqüências indomáveis pela noção de circularidade. Sua crítica foi, como freqüentemente acontece em seus textos, endereçada a Platão e evidencia como o princípio metafísico do ciclo (ou de qualquer tempo) está, como propôs Pomian, sujeito às conseqüências do argumento que pode linearizá-lo. Aristóteles critica Platão basicamente por tomar a roda do tempo como um fator suficiente para as mudanças, não indo às causas reais (desigualdades, facções, interesses etc.) como ele. As revoluções em sentido contrário ao ciclo, que Platão na verdade não fecha, também não são explicadas pelo modelo circular e Aristóteles arremata dizendo que há mais de um tipo de democracia como de oligarquia, perspectiva desconsiderada por Platão. A crítica tem início assim: "Na República, o problema das revoluções foi discutido por Sócrates, porém sua exposição não é correta. À sua constituição ideal, com efeito, constituição que é também a primeira, não se atribui nenhuma causa específica de mudança. Pois se dá como causa disto que nada permanece, senão que tudo muda dentro de um certo ciclo de tempo e que o princípio disso se radica nesses números "cuja base espiritual, conjugada com o número cinco dá lugar a duas harmonias", significando isso o momento em que o número da figura assim obtida se faz sólido, época em que a natureza engendra homens vis e mais tenazes que qualquer educação" (idem, p. 903) ${ }^{15}$.

É improvável que Aristóteles estivesse investindo contra a noção de ciclo como tal e estivesse fundando uma nova visão de tempo. Porém, a crítica não fica obscura se sua cronosofia, aplicada exclusivamente ao mundo sublunar (onde se situa a vida biológica e histórica), for tomada como uma noção, na qual o entendimento da circularidade do tempo não exclui a linearização do mesmo, embora o princípio de corrupção, motor do ciclo, seja imanente à esfera material do mundo. No texto aristotélico os dados da realidade alteram a circularidade e a própria seta da direção do tempo, linearizando-o para efeitos analíti$\cos$. O filósofo pode conceber a mesma realidade metafisicamente como fiel ao tempo da natureza: nascimento, crescimento, corrupção, morte e renascimento.

15 J. Morrall observa que é duvidoso que Platão pensasse em um modelo cronológico ao estabelecer sua seqüência de degeneração das formas de governo (MORRALL, 1981). Platão não fecha seu ciclo histórico, como Aristóteles também não o faz. Segundo Bignotto, a noção de uma circularidade inescapável e que teve grande influência no renascimento e no próprio Maquiavel, aparece mais claramente em Políbio, ainda de acordo com o mesmo autor, o tema da circularidade do tempo não é tratado profundamente por Aristóteles na Física ou na Metafísica (BIGNOTTO, 1994, p. 183-188). 
O conceito de tempo, como Aristóteles opera em um dos seus tratados mais esotéricos, é essencialmente platônico: imóvel para o ser (a geração ininterrupta) e móvel à medida que se acerca das esferas do mundo sublunar, onde tudo cambia pelo princípio da corrupção. Em uma passagem do seu tratado Acerca da geração e da corrupção (ARISTÓTELES, 1987), após reafirmar a canônica proposição de que para existir o movimento é necessário que haja um motor e, sendo o movimento eterno, é preciso que haja um motor eterno "uno, idêntico, imóvel, não gerado e inalterável" Aristóteles compatibiliza o movimento eterno com a circularidade do tempo. Suas palavras: "como o tempo é contínuo, necessariamente é contínuo o movimento, já que é impossível que o tempo exista independentemente do movimento. Pois o tempo é a numeração de algo contínuo e, logo, do movimento circular, tal como o determinamos em nossos tratados iniciais". E, mais adiante: "Porém o que se move, só é contínuo se movendo em círculo, de sorte que ele é sempre contínuo consigo mesmo" (idem, p. 113-117).

Assim, pode-se conjecturar que Platão, nesse caso, ressoa em Aristóteles: o círculo perfeito é a imagem da imobilidade do motor eterno. A corrupção de todas as formas geradas é um dado da natureza que se traduz no movimento circular do tempo. O problema é que essa noção metafísica do tempo atado à continuidade circular não pode ser transportada sem problemas para as formas de governo, cuja sucessão empírica afasta-se caoticamente do modelo determinista da circularidade. Diante disso, Aristóteles fugiu de aplicações rigorosas dessas idéias na esfera política, preferindo, em uma solução extremamente feliz, discutir as corrupções inevitáveis das formas de governo, a partir da análise dos modos como os homens organizam seus interesses e conflitos para construir uma polis estável. Essa solução será semelhante para os intérpretes renascentistas da política, que tinham problemas de análise concreta da história, vivendo em um tempo em que se procurava imitar concepções metafísicas da Antigüidade sobre a ordem do universo. E nem sempre era possível produzir sistemas coerentes a esse respeito, como o próprio Aristóteles percebeu.

\section{POR SEU TURNO, MAQUIAVEL}

O tempo implicado ou explicitado no texto de Maquiavel estava submetido a intenções retóricas e o autor, com grande probabilidade, tentava persuadir alguns espectadores em particular. Assim, seu texto com grande facilidade elogia e critica Roma conforme as necessidades de seu argumento. A tese contida em sua obra, de que um príncipe virtuoso poderia seduzir a fortuna e expulsar os bárbaros da Itália, refundando solitariamente a república, leva tanto à imitação dos antigos (ciclo), quanto à inovação (ruptura-linearização) representada por um agente sempre capaz de adaptar sua ação às condições do campo político. A pluralidade característica da república só poderia, naquelas condições históricas, ser salva, paradoxalmente, pela ação de um só. Por aqui se articulam o capítulo nono, livro um, dos Discorsi, e a exortação que encerra o Príncipe. Em ambos, Maquiavel considera que a salvação de uma república deve depender da ação de um príncipe com vontade própria e não de um conselho de notáveis. Conforme já foi assinalado por alguns especialistas, tal concepção da unificação de uma república não se enquadra mais na chamada tradição do humanismo cívico florentino, no qual a concentração de poder em um indivíduo é identificada com a tirania (MAQUIAVEL, 1983, p. 143-147).

A adaptação da conduta aos tempos é a melhor maneira de sobreviver às vicissitudes da fortuna. Maquiavel trabalha com uma flexibilidade tática do ator: se os homens não mudam sua natureza de acordo com as circunstâncias, a fortuna mudará; e quase sempre para pior (GREENE, 1968, p. 258). A liberdade que Maquiavel permite-se na manipulação da história é tal que, muitas vezes, suas proposições seriam eliminadas em certos testes, nos quais uma mesma causa não pode produzir efeitos contrários. Mas em um contexto em que a história existe para ser interpretada e dela extraírem-se lições úteis ao presente, não se pode esquecer que as fontes devem possibilitar todas as conclusões possíveis. A introdução do livro dois dos Discorsi e seu capítulo primeiro fornecem elementos para uma crítica, não meramente retórica, da história, abrindo espaço para a ação do príncipe novo. A primeira frase já anuncia uma idéia especiosa se considerados os cânones da época: "Os homens elogiam o passado e se queixam do presente, quase sempre sem 
razão" (MAQUIAVEL, 1979, p. 189). Ora, o elogio do passado é um dos elementos da retórica do próprio Maquiavel, além de um princípio consagrado do chamado humanismo, e segue-se uma desconfiança dos historiadores, que no fim das contas orientam mal quem conhece a história apenas pelas fontes, sendo incapaz de interpretá-la de acordo com a adequação dos tempos. Em uma crítica contundente aos "partidários cegos de tudo que se fazia outrora" ele diz: "Quando se equivocam, como acontece quase sempre, isso se deve a várias razões. A primeira é que não se pode conhecer toda verdade sobre os acontecimentos da antigüidade; muitas vezes se oculta o que poderia trazer desonra aos tempos passados, enquanto se celebra, e amplia, tudo o que acrescenta a sua glória. Ocorre também que os escritores, em sua maioria, seguem a sorte dos vencedores, aumentando o que fizeram de glorioso para melhor ilustrar suas vitórias, e acrescentando à força dos inimigos que venceram; de modo que os descendentes de uns e de outros não podem deixar de admirá-los e de exaltar o seu tempo, fazendo-os objeto de homenagem e admiração" (ibidem).

É muito possível que Maquiavel considerasse essa observação aplicável a alguns estudos da história contemporânea. Mas o ponto que interessa é que ao admitir que os fatos não são por completo conhecidos e têm aspectos intencionalmente ocultos, o florentino permite pensar que usar a história como um exemplo significa sempre preencher tais lacunas, e isso só pode ser feito com conjecturas sobre o que quer se considere ser a verdade sobre o passado. A história é assim uma construção retórica do passado e seu campo de teste é a eficácia dessa elaboração na direção das ações do presente. Por isso, em seguida, o autor afirma a necessidade do olhar para o presente, pois a despeito do hábito de louvar o passado os indivíduos devem guiar-se pelas evidências de sua própria experiência. Retorna então formalmente ao ciclo: "porque as coisas desse mundo estão sempre em transição, ora as exaltamos, ora as rebaixamos" (ibidem). Porém, logo adiante, o ciclo será alterado em função da percepção do espaço onde a história ocorre. Ele afirma que a igual quantidade de bem e de mal da história apenas passa de um país para outro "embora o mundo, como um todo, permaneça imutável", e emenda: "A única diferença é que a parte do bem, que a princípio estivera com os assírios, passou para os medas, para os persas, depois para a Itália e
Roma. Como das ruínas de Roma não nasceu qualquer império duradouro que reunisse todas as suas virtudes, o bem se distribuiu por muitos países, que deram disso prova clamorosa: o reino da França, o Império dos turcos e do sultão. Mais recentemente os povos da Alemanha e, antes deles, os sarracenos, de tão grandes realizações, cujas se estenderam muito longe, derrubando o Império Romano oriental” (idem, p. 190).

Ainda que tudo seja descrito como uma permanência do mundo atado à roda da fortuna, o tempo implícito no processo de transferência geográfica da história não é circular, ao contrário, ele será fundamental em certas filosofias da história posteriores, nas quais a circularidade foi abolida. A idéia de uma história que se desenvolve migrando por distintos territórios é encontrada em Montesquieu e tem sua elaboração mais densa em Hegel. Em ambos não há mais circularidade para a história, ainda retomada em um autor como Vico (BOBBIO, 1980).

Após encerrar a introdução do livro dois reafirmando a virtude do passado comparado aos vícios do presente, segue-se o capítulo primeiro, em que ele desautoriza, de uma só vez, duas de suas fontes, Plutarco e Tito Lívio: "Muitos historiadores entre eles Plutarco - escritor de grande peso - sustentam que a expansão do Império Romano se deveu mais à sorte do que à virtude. Entre seus argumentos, Plutarco cita a confissão dos próprios romanos, que atribuíam suas vitórias à fortuna, deusa que tinha mais templos do que qualquer outra divindade. Tito Lívio parece também pensar assim, pois é raro, ao citar uma figura importante, que não mencione, ao lado seu valor, sua sorte. Este contudo não é o meu pensamento; e não creio que opinião diversa possa ser sustentada. Se nunca existiu outra república que tivesse feito conquistas iguais às de Roma, isto se deve a que nenhuma outra teve, desde o início instituições tão apropriadas para este fim" (MAQUIAVEL, 1979, p. 193).

O juízo que os romanos e seus historiadores faziam de si não é melhor que as evidências da interpretação que Maquiavel pôde extrair dos relatos parciais recolhidos do passado. No seu entender, a ação virtuosa poderia "espancar" e submeter a má fortuna que pairava sobre a Itália. $\mathrm{O}$ fazer, a ação efetiva, atua sobre o tempo, fazendo a roda da fortuna girar no sentido positivo, e cria um mundo novo, no qual o passado é um trilho 
incompleto para a ação. A fortuna dos povos parece não se encerrar nos controles dos governantes. Provavelmente Maquiavel sabia disso, mas sua única alternativa era defender veementemente o primado da ação virtuosa sobre os arranjos do destino. No entanto, como Ulisses navegando no mar Egeu sempre fugiu das adversidades, o agente maquiaveliano também pode realizar sua virtude, a despeito das inconstâncias da história, desde que saiba mudar com ela. Saber para que lado gira a roda é o primeiro passo para escapar dos seus desígnios.

\section{CONCLUSÕES: UMA IDENTIDADE NA RETÓRICA DO CONFLITO}

O conflito como causa, a um só instante, da ordem e do movimento rumo ao caos da desordem civil, recoloca filosofia política de Maquiavel em uma linha (ou ciclo) que pode, pelo menos analiticamente, remontar a Aristóteles, ou melhor, a um tipo de teoria política grega. A noção de circularidade imanente à repetição dos fatos não impede que uma reflexão sobre a mesma repetição instaure um fato novo, um ponto de fuga do círculo para uma ordem singular. Nos dois autores, o tempo não é uma entidade definida e determinista na esfera social. Qualquer configuração organizada e seqüencial da polis terá sido, tanto em Maquiavel quanto em Aristóteles, mais devida ao engenho humano, que uma concessão da ordem natural da história. Assim, pois, podemos marcar um desacordo com o texto de Bock no sentido de que há realmente uma contradição em propor que as discórdias podem ser construtivas, quando se opõem classes sociais distintas; e disruptivas, se têm origem em facções de classe ou em outras inúmeras causas de câmbio institucional. Desejamos opor a isso a observação de que, historicamente, o conflito "positivo" de classes só pode acontecer por meio de atores que encarnam facções da plebe ou da aristocracia. Há uma contradição que pode ser transposta pela retórica, ou o que chamamos analiticamente de "uso ambíguo argumento" ou "uso ambivalente": ele pode ser sustentado em direções opostas para precisamente persuadir os interlocutores de que a contradição não dissolve o "sistema" sobre o qual se constroem as teses. Essencialmente, essa ambigüidade tem origem na premissa metafísica da circularidade do tempo que permitia a idéia de um conflito constitutivo, imanente, como forma de estabilizar as constituições fadadas à corrupção natural gerada por outros conflitos. O tempo circular não podia corresponder aos dados da realidade política, nem para um grego que já vivia o ocaso da polis incorporada à forma império, nem para um diplomata de uma cidade-estado-republicana que convivia com uma Itália presa de estados nacionais unificados, como a Espanha e a França; assim, o conflito disruptivo tinha de ser considerado como a força de uma história na qual o ciclo não tem mais direção. É claro que tais proposições são um problema analítico contemporâneo, e de certo não preocupavam a Aristóteles ou a Maquiavel. Se, para toda a tradição antiga, o conflito é sempre negativo, é um mérito dos dois autores apontar as condições sociais e políticas para pensá-lo como força latente e estabilizadora, mas é crucial lembrar que isso não pode ser feito sem uma operação argumentativa: atar o conflito ao tópico do caminho do meio em Aristóteles (a frenagem constitucional da corrupção) ou à tópica da luta de classes como motor da glória em Roma, no caso de Maquiavel. Os mesmos autores vão ter menos clemência aos conflitos diuturnos da cidade, e para isso vão dissociá-los do tempo circular; um tópico de explicação da natureza que não podia ajustar-se às várias configurações da história.

Raul Francisco Magalhães (raul.magalhaes@ufjf.edu.br) é Doutor em Ciência Política Instituto Universitário de Pesquisas do Rio de Janeiro (Iuperj) e Professor de Ciências Sociais na Universidade Federal de Juiz de Fora (UFJF). 


\section{REFERÊNCIAS BIBLIOGRÁFICAS}

ARISTÓTELES. 1982. Política. In: Obras. Madrid: Aguilar.

1987. Acerca de la generación y la corrupción. Madrid: Gredos.

2009. Constituição dos atenienses. Lisboa: Fundação Calouste Gulbenkian.

BIGNOTTO, N. 1994. O círculo e a linha. In: . Tempo e História. São Paulo: Companhia das Letras.

BOBBIO, N. 1980. A teoria das formas de governo. Brasília: UNB.

BOCK, G. 1990. Civil Discord in Machiavelli’s Istorie Fiorentine. In: Machiavelli and Republicanism. Cambridge (UK): Cambridge University.

GREENE, T. 1968. The Flexibility of the Self in Renaissance Literature. In: The Disciplines of Criticism. New Haven: Yale University.

MAGALHÃES, R. F. 1998. Tempo e conflito. Um esboço das relações entre as cronosofias de Maquiavel e Aristóteles. Antropolitica, Niterói, n. 4, p. 31-48. Disponível em: http:// www.uff.br/antropolitica/revistasantro politicas/revista_antropolitica_04.pdf.Acesso em: 18.abr.2011.

2000. Racionalidade e retórica. Teoria discursiva da ação coletiva. Rio de Janeiro. Tese (Doutorado em Ciência Política). Instituto de Pesquisas Universitárias do Rio de Janeiro.

MAQUIAVEL, N. 1979. Comentários sobre a primeira década de Tito Livio. Brasília: UNB.
1983. Carta a Francesco Vettori, em Roma (10 de dezembro de 1513). In: . O príncipe. Rio de Janeiro: Civilização Brasileira. Musa

1994. História de Florença. São Paulo:

MEYER, M. 1998. Questões de retórica, linguagem razão e sedução. Lisboa: Ed. 70.

MOMIGLIANO, A. 1983. L'historie ancienne et l'Antiquaire. In:__. Problèmes d'historiografhie ancienne et moderne. Paris: Gallimard.

MORRALL, J. B. 1981. Aristóteles. Brasília: UNB.

NAGEL, E. \& NEWMAN, J. R. 2003. A prova de Gödel. São Paulo: Perspectiva.

PERELMAN, C. \& OLBRECHTS-TYTECA, L. 1996. Tratado da argumentação. A nova retórica. São Paulo: M. Fontes.

POMIAN, K. 1993. Ciclo. In: RUGGIERO, R. (org.). Enciclopédia Einaudi. V. 29, verbete "Tempo-Temporalidade". Lisboa: Imprensa Nacional.

SKINNER, Q. 1988. Maquiavel. São Paulo: Brasiliense.

1996. As fundações do pensamento político moderno. São Paulo: Companhia das Letras.

TOULMIN, S. 1997. The Uses of Argument. Cambridge (UK): Cambridge University.

WITTGENSTEIN, L. 1989. Fichas. Lisboa: Ed. 70. 